\title{
Potential of different crop species for nickel and cadmium phytoremediation in peri-urban areas of Varanasi district (India) with more than twenty years of wastewater irrigation history
}

\author{
Sumita Pal, ${ }^{1}$ Harikesh Bahadur Singh, ${ }^{1}$ Amitava Rakshit ${ }^{2}$ \\ 'Department of Mycology and Plant Pathology, Institute of Agricultural Science, Varanasi; \\ 2Department of Soil Science and Agricultural Chemistry, Institute of Agricultural Science, Varanasi, India
}

\begin{abstract}
Heavy metals introduced into soil by indiscriminate dumping along with irrigating with sewage effluent often lead to toxic accumulation of heavy metal ions, which not only impair soil productivity but also cause health hazards by entering into food chain via soil-plant-animal-atmosphere continuum. To evaluate the potential of different crop species for nickel (Ni) and cadmium (Cd) phytoremediation, fifteen crop species comprising of cereals, vegetables and flowers were collected from differentially contaminated soils (DTPA-Cd $5.7-6.75 \mathrm{mg} \mathrm{kg}^{-1}$, DTPA-Ni 16.50$20.85 \mathrm{mg} \mathrm{kg}^{-1}$ ). The tissue metal concentration and relative efficiency of transfer of heavy metals from soil to plant (transfer factor) for various groups of crops were worked out. The uptake of $\mathrm{Cd}$ and $\mathrm{Ni}$ increased with contents in soils and the major part of taken up $\mathrm{Cd}$ and $\mathrm{Ni}$ is translocated to the floricultural crops with maximum accumulation occurred in roots. Values of translocation factor of $\mathrm{Cd}$ and $\mathrm{Ni}$ were ranged between 0.2 to 0.8 and 0.2 to 1.0 respectively for the different crops studied. The mean total root colonization by arbuscular mycorrhiza in these soils ranged from $15 \%$ for cauliflower to $76 \%$ for marigold, suggesting a certain adaptation of these indigenous to such environmental stress. Among the different crops studied marigold with highest translocation factor, mycorrhization and $\mathrm{Cd}$ and $\mathrm{Ni}$ content in root part holds considered as a potential economic crop for phytoremediation.
\end{abstract}

Correspondence: Sumita Pal, Department of Mycology and Plant Pathology, Institute of Agricultural Science, BHU, Varanasi, 221005, India.

E-mail: sumita.kgp.06@gmail.com

Key words: waste water, $\mathrm{Ni}, \mathrm{Cd}$, phytoremediation, cereals, vegetables, flowers.

Acknowledgments: the first author thanks the Department of Science \& Technology, New Delhi for the award of Woman Scientist Scheme (SRWOSA/S-17/2011) during the course of study.

Received for publication: 22 September 2012.

Revision received: 7 February 2013.

Accepted for publication: 8 February 2013.

○Copyright S. Pal et al., 2013

Licensee PAGEPress, Italy

Italian Journal of Agronomy 2013; 8:e8

doi:10.4081/ija.2013.e8

This article is distributed under the terms of the Creative Commons Attribution Noncommercial License (by-nc 3.0) which permits any noncommercial use, distribution, and reproduction in any medium, provided the original author(s) and source are credited.

\section{Introduction}

With increasing heavy metal contamination due to various anthropogenic and geogenic activities, ecosystems are being contaminated with heavy metals (HMs). Among anthropogenic events, application of municipal or industrial and sewage wastewater for irrigating agricultural crops, mainly in peri-urban ecosystem, due to its easy availability, disposal problems and scarcity of fresh water is most common. Municipal or industrial and sewage wastewater is most commonly used for irrigating agricultural crops, mainly in peri-urban ecosystem, due to its easy availability, disposal problems and scarcity of fresh water.

Continuous irrigation with wastewater is known to enrich significantly to the heavy metals content of soil resulting soil contamination, but also affect food quality and safety (Muchuweti et al., 2006). As a result of continuous irrigation with wastewater the concentration of HM (ubiquitous, highly persistent non bio-degradable ductility, conductivity, stability as cations, ligand specificity atomic weight $>5 \mathrm{mg}$ $\mathrm{m}^{-3}$ and atomic number $>20$ ) increases resulting soil contamination and also known to cause membrane damage, structural disorganization of organelles, impairment in the physiological functioning of the plants and ultimately growth retardation (Kimbrough et al., 1999; Chien and Kao, 2000; Zhang and Chen, 2002).

Although traditional methods for cleaning contaminated soil, such as ion-exchange and ultra-filtration, have proven to be efficient, they may not be economically feasible because of their relatively high cost, particularly when used for the removal of heavy metals at low concentrations (<100 mg/L) (Sangi et al., 2007; Torresday et al., 2005). Contaminated soil can also be remediated by chemical, physical or biological techniques. The available techniques may be grouped into two categories: i) ex situ techniques, which require removal of the contaminated soil for treatment on or off site, and ii) in situ methods, which remediate without excavation of contaminated soil. In situ techniques are favoured over the $e x$ situ techniques due to their lower cost and reduced impact on the ecosystem.

It is interesting to notice that there are plants that survive, grow and reproduce on natural as well as on sites polluted with heavy metals as a result of anthropogenic activities. A persistently medium to high level of available heavy metal in the soil solution has led to numerous morphological, physiological, and biochemical adaptations by plants to survive in the nature. Crop species differ in their ability to grow well in these soils (Macnair, 2003). Possible reasons for this variation of ability among the crops during the growing season may have been due to processes, mainly differential growth habit, the action of arbuscular mycorrhize (AM) (Marschner, 1995), and rate of root exudation (Gerke et al., 1994).

Among all existing in situ methods, the use of green plants to extract, sequester, and detoxify non-volatile and immiscible pollutants, has shown considerable promise as a low-cost technique and has 
received much attention in recent years. Additionally, this sustainable and inexpensive method is environmentally friendly and the soil can be utilized immediately after treatment (Pulford et al., 2001) particularly with fast growing plants and with high metal uptake ability and rapid biomass gain are needed. Again heavy metals are partitioned in different parts of the plant according to nature of crops, species and season. Plants have evolved several mechanisms to maintain ion homeostasis under elevated HM concentrations (Clemens, 2001). Heavy metals are easily accumulated in the edible parts of leafy vegetables, as compared to grain, fruit or flower crops. Furthermore, association of mycorrhize may improve the HM tolerance (Baker, 1987) as their populations are critical during and after soil disturbance because of their role in the establishment and survival of plants.

In a preliminary investigation of remediation options for the periurban areas of Varanasi contaminated with heavy metal in particular nickel (Ni) and cadmium (Cd) warrants to search for an indigenous hyper-accumulating species within the existing cropping sequence (Pal et al., 2012). However, after thorough investigation through questionnaire feedback by participatory research appraisal of the area and considering the needs of the local people, another important criterion have to be added for the search of potential plants, i.e., provision of economic benefits to the farmers.

Several researchers have reported that differences in HM tolerance efficiency are based on size and type of the root system i.e. root length, root radius and root hair density and rate of shoot growth rate (Föhse et al., 1991). Furthermore, association of mycorrhizae may improve the HM tolerance (Yost and Fox, 1979). Therefore, for a better understanding of the HM tolerance efficiency of a plant, its uptake and use has to be analysed.

From the above-discussed results, it can be inferred that both the plants developed mechanisms to survive in those soils of HM availability. We speculated that the mechanisms could be the action of AM. Most studies to investigate the significance of AM have been done in pots with sterilized and AM-re inoculated soil. Few studies have been carried out using biocides like dazomet (Jakcobsen, 1986) under field condition. Keeping in view all the above points the present investigation was undertaken to study the build- up of heavy metals in soil and compare the heavy metal concentration profile of different crops grown resulting due to long term irrigation of wastewater. Additionally from the study of translocation of heavy metals in the plants was also attempted to find the potential of different crop species for phytoremidiation of $\mathrm{Cd}$ and $\mathrm{Ni}$ and assess the significance of $\mathrm{AM}$ for the increased heavy metal tolerance.

\section{Materials and methods}

\section{Experimental site}

A reconnaissance survey was conducted in urban and suburban areas of Varanasi to identify the locations where wastewater from industries and municipa//domestic sewage is currently used for irrigation of crops. Interviews with government authorities and farmers helped to identify areas where wastewater irrigation has been common practice for many years, and where the irrigation water can be clearly sourced to treated or untreated industrial effluent. The area selected for the study was an urban fringe subtropical area of Varanasi city, situated in the Eastern Gangetic plain (25 $18^{\prime} \mathrm{N}$ latitude and $83^{\circ} 01^{\prime} \mathrm{E}$ longitude) of northern India with an average annual rainfall of $1100 \mathrm{~mm}$ and a mean annual temperature ranges between $20-42^{\circ} \mathrm{C}$ and $9-28^{\circ} \mathrm{C}$ respectively. The sampling locations selected at the northeast of the city center are Mustafabad $\left(25^{\circ} 21.014^{\prime} \mathrm{N}, 83^{\circ} 07.787\right.$ ' E), Chiraigoun $\left(25^{\circ} 21.100^{\prime} \mathrm{N}, 83^{\circ} 07.625^{\prime} \mathrm{E}\right)$, Chandpur ( $\left.25^{\circ} 20.848^{\prime} \mathrm{N}, 83^{\circ} 06.414^{\prime} \mathrm{E}\right)$ Singhwar $\left(25^{\circ} 20.595^{\prime} \mathrm{N}, 83^{\circ} 05.238^{\prime} \mathrm{E}\right)$ and Kamoli $\left(25^{\circ} 20.511^{\prime} \mathrm{N}\right.$, $83^{\circ} 04.352$ ' E). This field site has been contaminated by surface application of sewage sludge and surface irrigation with wastewaters (with average total suspended solid: $485.6 \mathrm{mgL}^{-1}$, total dissolved solid: 995.2 $\mathrm{mgL}^{-1}$, nitrogen: $0.41 \mathrm{ppm}$ and $\mathrm{Cd}$ : $0.2 \mathrm{ppm}$ ) since the $1990 \mathrm{~s}$. The impact of the wastewater toxicants on the environmental quality of the disposal area was assessed in terms of their levels in different media samples viz., soil and crops.

\section{Soil sample collection}

Soil samples were collected in triplicate from rhizosphere of respective crop species at a depth of 0-30 cm and combined to give approximately 500 g soil. Roots were separated and then $100 \mathrm{~g}$ air-dried soil was employed for extraction of arbuscular mycorrhizal fungal spores. Rest were air dried, crushed, and passed through 2-mm-mesh sieve and stored at ambient temperature before analysis of soil properties and concentrations of heavy metals by standard soil analysis technique. The plant available $\mathrm{Cd}$ and Ni were extracted by DTPA solution and analysed in atomic absorption spectrophotometer. The $\mathrm{pH}$ of soils were determined used a combined electrode (Jackson, 1973) and electrical conductivity by conductivity meter (1:2.5 soil water suspension); organic matter by chromic acid wet digestion method (Walkley and Black, 1934), plant available nitrogen by alkaline permanganate method (Subbiah and Asija, 1956), phosphorus by $\mathrm{NaHCO}_{3}$ (Olsen et al., 1954), potassium by flame photometry (Jackson, 1973) and plant available Cd and Ni were extracted by DTPA solution and analysed in atomic absorption spectrophotometer. Metal concentrations and the selected soil properties are showed in Table 1. According to the Indian National Standards Institution (Awashthi, 2000), this soil is seriously contaminated with $\mathrm{Cd}, \mathrm{Pb}$ and $\mathrm{Zn}$, as described in previous studies (Sharma et al., 2007; Singh et al., 2010).

\section{Plant sample collection}

Sample collection in triplicate was carried out in November 2011 during rabi (winter) season from the same field simultaneously. Most common crops include Rice (Oryza sativa L), Jowar (Sorghum bicolor) and Bajara (Pennisetum typhoides L) among the cereal crops. Among vegetable grown at all the study sites was palak (Beta vulgaris L. var. All green H1), radishes (Raphanus sativus), tomatoes (Lycopersicum esculentum), lady's finger (Abelmoschus esculentus), cauliflower (Brassica oleracea var. acephala), cabbage (Brassica oleracea var. capitata), Brinjal (Solanum melongena), Pea (Pisum sativus), Spinach (Spinacea oleracea), Spong guard (Luffa cylindrica) and carrots (Daucus carota). These vegetable crops are mainly produced for home consumption and sale to residential areas of urban and suburban region of Varanasi. Among floricultural crop marigold (Tagetes erecta), bela (Jasminum sambac) and gudhal (Hibiscus rosa-sinensis) are most prominent. Among the fruits papaya (Carica papaya), guava (Psidium guajava) and citrus (Citrus spss) are most prominent. Care was taken to get samples of the same varieties and age group.

\section{Plant sample processing}

Samples were washed using clean water and then separately ovendried at $70^{\circ} \mathrm{C}$ till constant weight was achieved. The samples were then crushed separately through a steel grinder and the crushed material was passed through 2-mm sieve. The sieved samples were kept at ambient temperature before analysis. For crop samples, $0.5 \mathrm{~g}$ of dried samples were digested with $15 \mathrm{~mL}$ of $\mathrm{HNO}_{3}, \mathrm{H}_{2} \mathrm{SO}_{4}$, and $\mathrm{HClO}_{4}$ in 5:1:1 ratio at $80^{\circ} \mathrm{C}$ until a transparent solution was obtained (Allen et al., 1986). The solution was filtered through Whatman No. 42 filter paper and the solution was diluted to $50 \mathrm{~mL}$ with distilled water. The concentrations 
of heavy metal in filtrate of water, soil, and plant samples were determined with an atomic absorption spectrophotometer fitted with a specific lamp of a particular metal using appropriate drift blanks.

\section{Root sample processing}

Roots were carefully separated from soil by washing and flooding over sieves. After cleaning of any foreign material, fresh root biomass was divided in two parts. One part were then oven-dried in a hot air oven at $70-80^{\circ} \mathrm{C}$ for $24 \mathrm{~h}$, to remove all moisture. Dried samples were powdered using a pestle and mortar and the concentration of heavy metal was determined in the similar procedure as mentioned above.

\section{Percentage root infection with arbuscular mycorrhiza}

Remaining part of root were cut into $1-1.5 \mathrm{~cm}$ lengths. Root samples were stained with trypan blue (Phillips and Hayman, 1970). Mycorrhiza infection of each plant was determined by estimating the per cent of root segments colonised with AM as described by Bierman and Linderman (1981). Alkaline hydrolysis of root samples with $10 \%$ potassium hydroxide was done at $90^{\circ} \mathrm{C}$ in an oven for $8-10$ min to clear the plant cytoplasm depending upon the stiffness of the root. The roots were then washed in several changes of water and then treated with 1 $\mathrm{N}$ hydrochloric acid for $10 \mathrm{~min}$ and ultimately stained by $0.05 \%$ tryptan blue (made in lactophenol) for about $24 \mathrm{~h}$. A minimum of 50 root fragments was examined at each time. Percent root infection was obtained as follows:

$\%$ Root infection $=$

$(100 \times$ Number of root segments infected with arbuscular infections) /

Total number of segments counted.

Simple correlation analysis was performed to test the influence of heavy metal content on enzyme activities in response to different crop species. The difference between means of different sites were tested by applying one-way analysis of variance and the difference in the mean heavy metal concentration and TF among vegetables were tested by Duncan's multiple range test at $\mathrm{P}<0.05$ (wherever normality and homoscedasticity was maintained).

All statistical analysis was computed with the software package SPSS (ver. 10.0).

\section{Results and discussion}

The main properties of the rhizospheric soil are represented in Table 1. Soil $\mathrm{pH}$ ranged from neutral to slightly alkaline, while organic matter and total nitrogen was low. Electrical conductivity, organic carbon, available phosphorus, and available potassium were medium to low in the soils. Cadmium was significantly higher in these soils compared to Nickel.

Measurements of several enzymatic activities have been used to establish indices of soil fertility (Beck, 1984; Stefanic et al., 1984; Pascual et al., 2000). Enzymes are synthesized by microorganisms and plants, and in the soil they act as biological catalysts of important reactions to produce essential compounds for both soil microorganisms and plants. Enzymatic activities may vary under stress, as when soil is contaminated by heavy metals (Dick, 1997). The effect of heavy metals in particular $\mathrm{Cd}$ and $\mathrm{Ni}$ on different soil enzymatic activities has been studied and presented in Table 1.

In general, enzymatic activity diminished with increasing concentration of $\mathrm{Cd}$ and $\mathrm{Ni}$ except urease (Cd: $r=0.70 ; \mathrm{Ni}: r=0.66, \mathrm{P}<0.05)$. Both $\mathrm{Cd}$ and Ni inhibited soil phosphatase activity (ACP $>$ ALP) (Table 1). We
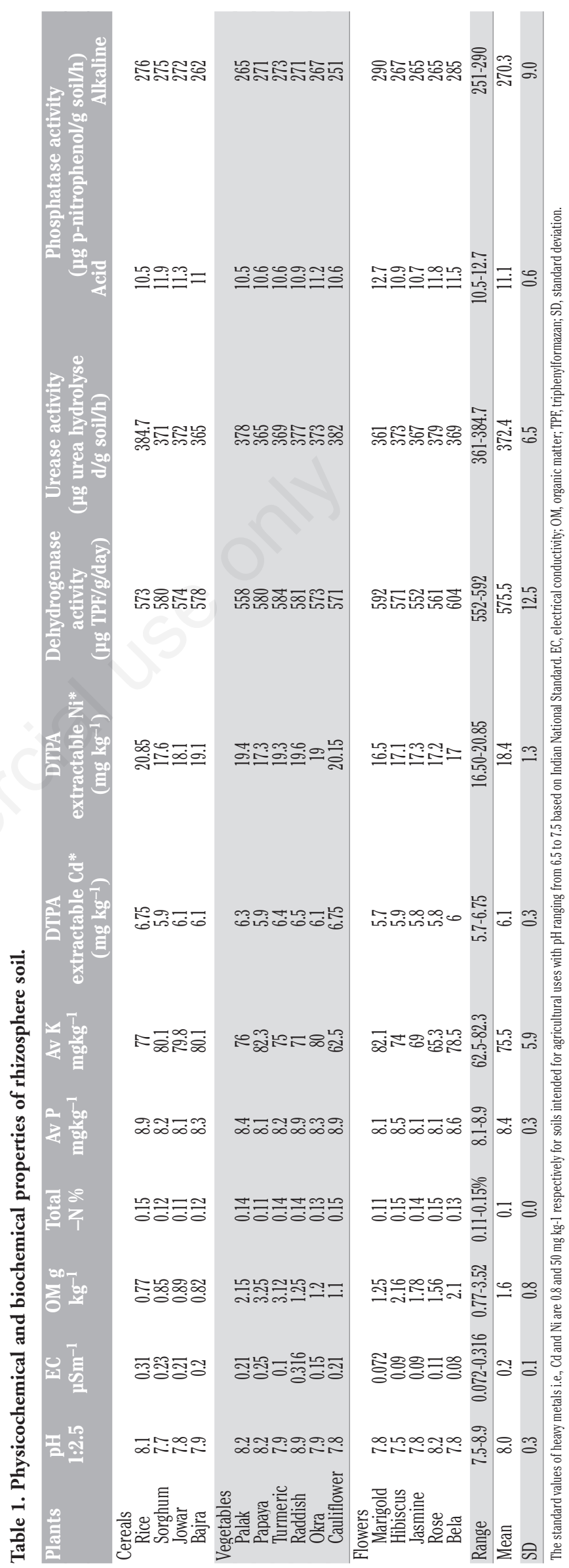
found that dehydrogenase was the most sensitive enzyme. This might be due to lower ecological dose values of $\mathrm{Cd}$ than those of $\mathrm{Ni}$, indicating that $\mathrm{Cd}$ had a greater effect on the hydrolytic activity of the enzymes studied.

The mobility of the heavy metals from the polluted substrate into the roots of the plants and the ability to translocate the metals from roots to the harvestable aerial part were evaluated respectively by means of the bioaccumulation factor (BAF) and the translocation factor (TF) and presented in Table 2.

The aim of this study was to evaluate the potential of different crop species to uptake $\mathrm{Cd}$ and $\mathrm{Ni}$ from the soil. Plants differ in their uptake of heavy metals and the subsequent distribution of metals within plant organs. Comparing the plant organs in this study showed that roots accumulate higher concentrations of $\mathrm{Cd}$ and $\mathrm{Ni}$ than other organs which resulted in the redistribution of metals in soil (Table 2), thereby reducing these elements concentration in the soil surface via leaf decomposition, which may represent a risk to the food chain. This knowledge is important for the selection of the most appropriate technology for processing metal-enriched plant material after harvest and can help in phytoremediation management.

Translocation factor was calculated for assessing the translocation of $\mathrm{Cd}$ and Ni from root to shoot. Values of translocation factor of $\mathrm{Cd}$ were ranged between 0.2 to 0.8 for the different crops studied. Further it is evident from the table that translocation factor of $\mathrm{Ni}$ for the crops ranged between 0.2 to 1.0 . Although the values of translocation factor for all the plant species are below 1, these could not be regarded as hyper-accumulators (Hooda 2007; Baker and Walker, 1989) yet the results suggested that by and large the major part of taken up $\mathrm{Cd}$ and $\mathrm{Ni}$ is translocated to the floricultural crops. As the plants take up $\mathrm{Cd}$ and $\mathrm{Ni}$ readily and there is least possibility of its translocation to flowers and excessive accumulation, concentrated in plant organs and devaluation of the plant products does not arise. This is an issue particularly advantageous in crops not used for direct consumption. For most of the crop studied heavy metals that do enter the plant are then kept in root cells, where they are detoxified by complexation with amino acids, organic acids or metal-binding peptides and/or sequestered into vacuoles. This greatly restricts translocation to the aboveground organs thus protecting the leaf tissues, and particularly the metabolically active photosynthetic cells from heavy metal damage. A further defence mechanism generally adopted by heavy metal-exposed plants is enhancement of cell antioxidant systems, which counteracts oxidative stress. As a rule, heavy metals are less accumulated in generative parts of the plants compared to vegetative ones, and often roots are the main accumulative organs or sinks for heavy metals (Ford and Hasselbach, 2001). From the Table 2 looking at the internal metal allocation between roots and shoots it is evident that most of the plant species retain maximum metals in their roots and restrict metal transfer into the shoots and can be categorised as excluders. But exclusion is not avoidance at the whole plant level, because the uptake by the root has to meet a plant's demand for i) the primary metabolic processes, and ii) the defence function.

In the present study, AM association was recorded (Table 3 ) in plants which was characterized by the presence of hyphae, intracellular arbuscules, intercellular vesicles and spores (Figure 1).

AM fungal spore varied greatly between plant species. AM fungal species belonging to the genus Glomus were found in rhizosphere samples of different crop species. The ability of Glomus to dominate soil rhizosphere indicated that Glomus has a broad host range and the spores of Glomus species have different temperature and $\mathrm{pH}$ preferences for germination (Wang et al., 1997). Host plant also had a significant effect on the total AM spores produced in the rhizosphere, Sorghum bicolor being the trap plant that produced AM spores most effectively possibly because of the higher root growth rate of this plant species, which can facilitate further contact with most AM fungi (AMF) present in the soil. Host plants also exerted a differential effect on AMF diversity, with $T$. erecta and $S$. bicolor promoting significantly higher number as well as levels of diversity in their rhizospheres than those produced by cauliflower and raddish. Therefore, the selection of plant rotation on AM is significant and should be considered in field management. Variation in spore density and AMF colonization in relation to host plants can be linked to factors such as plant phenology, dependency on mycorrhiza, changes in the soil microenvironment, or unknown host characteristics. Total AM spore number decreased significantly with increasing amounts of heavy metals in soil, from 330 spores (per $100 \mathrm{~g}$ of dry soil) in marigold with a heavy metal $(\mathrm{Cd}+\mathrm{Ni})$ content 23.5 $\mathrm{mg} \mathrm{kg}-1$ to 56 spores in cauliflower with a heavy metal content $26.90 \mathrm{mg}$

Table 2. Heavy metals content in plant samples.

\begin{tabular}{|c|c|c|c|c|c|c|c|c|c|c|}
\hline \multirow[t]{2}{*}{ Plants } & \multicolumn{5}{|c|}{$\mathrm{Cd}\left(\mu \mathrm{g} \mathrm{g}^{-1}\right)$} & \multicolumn{5}{|c|}{ Ni $\left(\mu g g^{-1}\right)$} \\
\hline & $\operatorname{Root}\left(C_{r}\right)$ & $\operatorname{Shoot}\left(\mathrm{C}_{\mathrm{s}}\right)$ & Soil & $\mathrm{TF}=\mathrm{C}_{\mathrm{s}} / \mathrm{C}_{\mathrm{r}}$ & $\mathrm{BAF}=\mathrm{C}_{\mathrm{p}} / \mathrm{C}_{\mathrm{so}}$ & $\operatorname{Root}\left(\mathrm{C}_{\mathrm{r}}\right)$ & Shoot $\left(\mathrm{C}_{\mathrm{s}}\right)$ & Soil & $\mathrm{TF}=\mathrm{C}_{\mathrm{s}} / \mathrm{C}_{\mathrm{r}}$ & $\mathrm{BAF}=\mathrm{C}_{\mathrm{p}} / \mathrm{C}_{\mathrm{so}}$ \\
\hline \multicolumn{11}{|l|}{ Cereals } \\
\hline Rice & 0.1 & 0.04 & 6.7 & $0.4^{c}$ & $0.01^{\mathrm{j}}$ & 2.65 & 0.53 & 20.1 & $0.2^{\mathrm{g}}$ & $0.03^{\mathrm{k}}$ \\
\hline Sorghum & 0.68 & 0.21 & 3.1 & $0.3^{c}$ & $0.17^{\mathrm{d}}$ & 3.1 & 2.5 & 15.3 & $0.8^{b}$ & $0.16^{\mathrm{d}}$ \\
\hline Jowar & 0.53 & 0.15 & 5.7 & $0.3^{c}$ & $0.07^{\mathrm{fg}}$ & 3.5 & 2.9 & 16.1 & $0.8^{b}$ & $0.18^{c}$ \\
\hline Bajra & 0.55 & 0.21 & 6.1 & $0.4^{c}$ & $0.06^{\mathrm{g}}$ & 1.68 & 1.4 & 16.5 & $0.8^{b}$ & $0.08^{g}$ \\
\hline \multicolumn{11}{|l|}{ Vegetables } \\
\hline Palak & 4.76 & 2.14 & 6.8 & $0.4^{c}$ & $0.31^{\mathrm{a}}$ & 0.5 & 0.23 & 20.5 & $0.5^{\mathrm{d}}$ & $0.01^{1}$ \\
\hline Рарауа & 0.35 & 0.06 & 5.1 & $0.2^{d}$ & $0.04^{\mathrm{h}}$ & 3.97 & 0.51 & 16.8 & $0.1^{\mathrm{h}}$ & $0.16^{\mathrm{d}}$ \\
\hline Turmeric & 0.38 & 0.16 & 6.5 & $0.4^{c}$ & $0.02^{i j}$ & 2.04 & 0.34 & 21 & $0.2^{\mathrm{g}}$ & $0.05^{\mathrm{i}}$ \\
\hline Raddish & 0.52 & 0.21 & 6.5 & $0.4^{c}$ & $0.03^{\text {hi }}$ & 2.59 & 1.31 & 20.6 & $0.5^{\mathrm{d}}$ & $0.06^{\mathrm{h}}$ \\
\hline Okra & 0.45 & 0.18 & 6.4 & $0.4^{c}$ & $0.04^{\mathrm{h}}$ & 2.48 & 0.85 & 19.3 & $0.3^{\mathrm{f}}$ & $0.06^{\mathrm{h}}$ \\
\hline Cauliflower & 4.9 & 0.78 & 6.4 & $0.2^{\mathrm{d}}$ & $0.12^{\mathrm{e}}$ & 8.4 & 3.1 & 21.5 & $0.4^{\mathrm{e}}$ & $0.14^{\mathrm{e}}$ \\
\hline \multicolumn{11}{|l|}{ Flowers } \\
\hline Marigold & 1.69 & 1.42 & 4.7 & $0.8^{a}$ & $0.30^{\mathrm{ab}}$ & 4.05 & 3.85 & 15.6 & $1.0^{\mathrm{a}}$ & $0.25^{b}$ \\
\hline Hibiscus & 1.13 & 0.43 & 5.6 & $0.4^{c}$ & $0.11^{\mathrm{e}}$ & 2.15 & 0.7 & 17.8 & $0.3^{\mathrm{f}}$ & $0.04^{\mathrm{j}}$ \\
\hline Jasmine & 1.89 & 1.35 & 5.2 & $0.7^{b}$ & $0.26^{\mathrm{c}}$ & 2.43 & 1.95 & 15.8 & $0.8^{b}$ & $0.12^{\mathrm{f}}$ \\
\hline Rose & 0.81 & 0.24 & 5.9 & $0.3^{c}$ & $0.08^{f}$ & 1.9 & 1.05 & 18.9 & $0.6^{\mathrm{c}}$ & $0.06^{\mathrm{h}}$ \\
\hline Bela & 2.13 & 1.54 & 5.3 & $0.7^{\mathrm{b}}$ & $0.29^{b}$ & 3.65 & 3.24 & 15.7 & $0.9^{\mathrm{a}}$ & $0.27^{\mathrm{a}}$ \\
\hline
\end{tabular}

作 mulation factor (BAF) values are the means of three replicates. ${ }^{\text {a-i }}$ Within columns, values followed by different letters are significantly different $(\mathrm{P}>0.05)$. 
$\mathrm{kg}^{-1}$ (Ni: $r=-0.52, \mathrm{P}<0.05$ and $\left.\mathrm{Cd}: r=-0.56, \mathrm{P}<0.05\right)$. Firstly, the occurrence of several AMF in the soils or within roots suggests that inter specific competition between them is possible (Brundrett and Kendrick, 1990). Secondly, subsequent variation in the spore production occurs among AMF associated with host plants, suggesting that competition between fungi and environmental factors influence spore production in natural communities (Koske et al., 1992). The lower values in cauliflower may be due to the presence of fungi toxic compounds in root cortical tissue or in root exudates that may reduce susceptibility of plants to mycorrhization (Tester et al., 1987). The total number of AM spores strongly decreased with increasing amounts of heavy metals, but the AMF propagules never disappeared completely in soils irrigated with waste water for the last twenty five years, suggesting a certain adaptation of these indigenous AMF to such environmental stress. This fungitoxic effect of metal can cause inability by certain AM species' to colonize the root system and/or to multiply in the rhizosphere. Only AM species better adapted to the disturbance produced by the addition of metals would overcome the stress situation and complete their life cycles. Based on spore size and colour, wall structure, and hyphal attachment following species which were dominant as follows $G$. fasciculatum, $G$. intraradices, $G$. mosseae and several other unidentified species. Further $G$. fasciculatum seemed to be the AM species with the best ability to sporulate except in vegetables where $G$. mosseae was dominant. The mean total root colonization in these soils ranged from $15 \%$ for cauliflower to $76 \%$ for marigold. Crop plants show variations in their dependence on mycorrhizae for heavy metal tolerance based on factors such as root surface area, root hair abundance and length, growth rate, response to soil conditions and exudations. Responsiveness to mycorrhizal colonization changes with plant cultivars (Zhu et al., 2001). The AM can extend their hyphae over several tens of meters outside the rooting zone and transfer other types and amounts of chemical elements to the plant. These fungi, mostly having a higher metal tolerance than angiosperms, may enhance metal resistance of an angiosperm by changing metal speciation or by restricting the transfer of the metal into the plant.

Thus, in floricultural crops mycorrhiza can show enhanced HM uptake and root-to-shoot transport (phytoextraction) while in other cases AMF contribute to HM immobilization within the root and soil (phytostabilization). AMF exude enzymes that participate in the immobilization process of metals, AM colonization decreases the uptake and accumulation of metals in host plants (Joner and Leyval, 1997; Weissenhorn et al., 1993).

Field investigations have indicated that mycorrhizal fungi can colonize plant in metal contaminated sites (Díaz and Honrubia, 1993; Pawlowska et al., 1996) and in agricultural soils contaminated with metals. The ability to tolerate may involve mechanisms like fungal gene expression, extracellular metal sequestration and precipitation, production of metallothioneins (metal binding proteins), avoidance of metals (reduced uptake or increased efflux, formation of complexes outside cells, release of organic acids, etc.), intracellular chelation (synthesis of ligands such as polyphosphates and etallothioneins), compartmentation within leaf vacuoles, loss of leafs during dry or cold seasons, phosphorus plant status or interaction between $\mathrm{P}$ and metals (increased $\mathrm{P}$ uptake by host plant),biological sorption via glomalin and volatilization (Sudová et al., 2007).

\section{Conclusions}

As heavy metals can not be chemically degraded, remediation of metal-polluted soils is limited mainly to immobilization through phyto stabilization by promoting plant growth to reduce or eliminate the
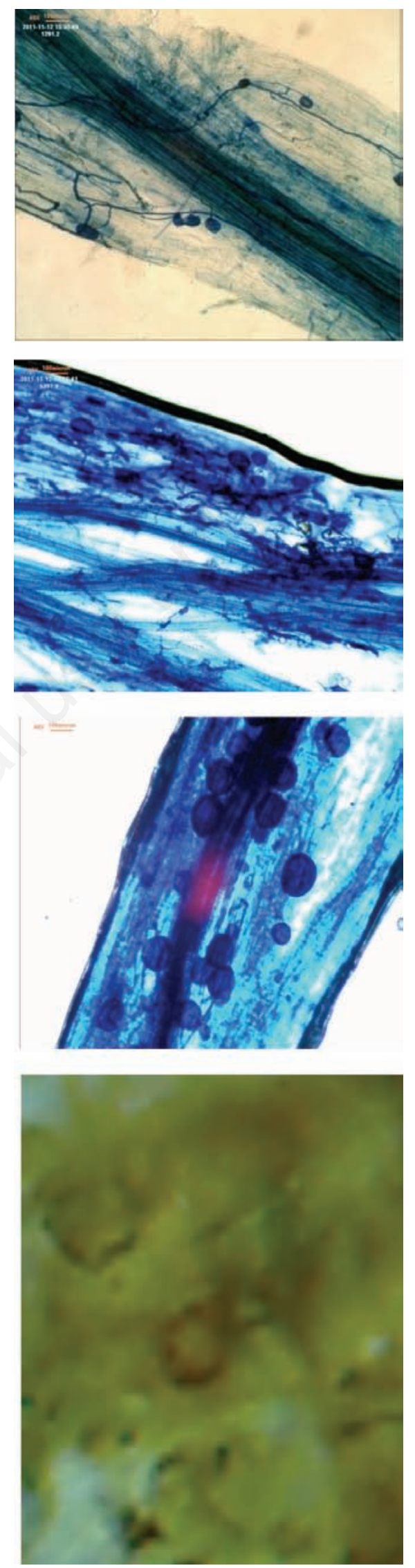

Figure 1. Presence of hyphae, intracellular arbuscules, intercellular vesicles and spores. 
bioavailability of metals. In this context, indigenous AMF constitute an important functional component of the soil-plant system that is critical for sustainable productivity in wastewater-amended soils. An important provision is that the cultivation of root and leafy vegetables (palak, raddish, etc.) is to be avoided in the growing season as crops for the human consumption. Since this study examined the wastewater usage with one year sampled observations, similar studies should continue under various conditions for a long time to exploit beneficial properties of the wastewater with other possible economical crops. However, considering the heavy metals that it contains, uncontrolled use should be

Table 3. Total number of arbuscular mycorrhiza fungi spores (AMF per $100 \mathrm{~g}$ of dry soil), species richness and diversity index in rhizosphere of different crops.

\begin{tabular}{lcc}
\hline Plants & AMF spores & Total root colonivation (\%) \\
Cereals & & \\
Rice & $94^{\mathrm{ef}}$ & $50^{\mathrm{e}}$ \\
Sorghum & $163^{\mathrm{b}}$ & $70^{\mathrm{b}}$ \\
Jowar & $160^{\mathrm{bc}}$ & $58^{\mathrm{c}}$ \\
Bajra & $151^{\mathrm{cd}}$ & $53^{\mathrm{d}}$ \\
Vegetables & & \\
Palak & $84^{\mathrm{fg}}$ & $18^{\mathrm{jk}}$ \\
Papaya & $166^{\mathrm{b}}$ & $36^{\mathrm{g}}$ \\
Turmeric & $84^{\mathrm{fg}}$ & $40^{\mathrm{f}}$ \\
Raddish & $72^{\mathrm{g}}$ & $24^{\mathrm{h}}$ \\
Okra & $154^{\mathrm{bcd}}$ & $55^{\mathrm{de}}$ \\
Cauliflower & $56^{\mathrm{h}}$ & $15^{\mathrm{k}}$ \\
\hline Flowers & & \\
Marigold & $330^{\mathrm{a}}$ & $76^{\mathrm{a}}$ \\
Hibiscus & $82^{\mathrm{fg}}$ & $24^{\mathrm{h}}$ \\
Jasmine & $105^{\mathrm{e}}$ & $19^{\mathrm{j}}$ \\
Rose & $75^{\mathrm{g}}$ & $21^{\mathrm{i}}$ \\
Bela & $145^{\mathrm{d}}$ & 34
\end{tabular}

Values are the means of three replicates. AMF, arbuscular mycorrhiza fungi. a-k Within columns, values followed by different letters are significantly different $(P>0.05)$.

Table 4. Averaged yields of different crop species under different package of practices.

\begin{tabular}{lccc} 
Plants & $\begin{array}{c}\text { Averaged } \\
\text { yields (tons/ha) }\end{array}$ & $\begin{array}{c}\text { Cost involved } \\
(€ / \text { ha) }\end{array}$ & $\begin{array}{c}\text { Costbenefit } \\
\text { ratio }\end{array}$ \\
Cereals & & & \\
Rice & 7 & 22,000 & $1: 1.23$ \\
Sorghum & 0.7 & 14,000 & $1: 1.25$ \\
Jowar & 1.2 & 14,500 & $1: 1.05$ \\
Bajra & 0.61 & 15,000 & $1: 1.37$ \\
Vegetables & & & \\
Palak & $8-10$ & 25,000 & $1: 1.40$ \\
Papaya & $60-75$ & 100,000 & $1: 2.64$ \\
Turmeric & 19.8 & 165,000 & $1: 1.90$ \\
Raddish & $15-16$ & 26,000 & $1: 1.40$ \\
Okra & $8-10$ & 70,000 & $1: 1.59$ \\
Cauliflower & $25-30$ & 72,000 & $1: 3.07$ \\
\hline Flowers & & & \\
Marigold & 30 & 50,000 & $1: 3.56$ \\
Hibiscus & 16.5 & 35,000 & $1: 2.75$ \\
Jasmine & 6.2 & 67,000 & $1: 2.50$ \\
Rose & 3 & 75,000 & $1: 2.1$ \\
Bela & 10 & 65,000 & $1: 2.05$ \\
\hline
\end{tabular}

The cost-benefit analysis was carried through interviewing with as many farmers as possible who could provide useful data for this survey. Questions were oriented more towards physical quantities of inputs and outputs, prices and unit costs, rather than cash outlays. avoided. Therefore with the advantage of secondary economically viable use, the flower crops particularly marigold have a potential considering the high biomass production and cost involved (Table 4) among the crops existing in the cropping system and that too the nonhazardous, these can act as viable candidate for phyto-remediation minimising the risks of $\mathrm{Cd}$ and $\mathrm{Ni}$ entering into the food chain. Additionally in the religious places including Varanasi in India, it will be easy to convince local people to grow these hyper-accumulators in their yards for the sole purpose of removing pollutants from their environment as well as it offers guaranteed financial remuneration. Besides, since AMF cannot be grown without a host plant (Leyval and Joner, 2001) and may coexist with other microbial communities (Roesti et al., 2005; Toljander, 2006) that can tolerate and accumulate metals (Lepp, 1992), this would obscure the interaction between AMF and metals in the substrate. By using specific fungal strains isolated from this polluted site, will improve tolerance to heavy metals and the techniques could be optimized looking into the economics of cultivation of different crop species.

\section{References}

Allen SE, Grimshaw HM, Rowland AP, 1986. Chemical analysis. In: P.D. Moore and S.B. Chapman (eds.) Methods in Plant Ecology. Blackwell Scientific Publication, Oxford, London, UK, pp 285-344.

Awashthi SK, 2000. Prevention of Food Adulteration Act no. 37 of 1954. Central and State Rules as Amended for 1999, third ed. Ashoka Law House, New Delhi, India. Baker AJM, Walker PL, 1989. Physiological responses of plants to heavy metals and the quantification of tolerance and toxicity. Chem. Spec. Bioavailab. 1:7-17.

Baker AJM, 1987. Metal tolerance. New Phytologist 106:93-111.

Beck T, 1984. Methods and application of soil microbial analyses at the Landensanstalt fur Bodenkulturund Pfl anzenbau (LBB) in Munich for the determination of some aspects of soil fertility. 5th Symp. on Soil Biology. Roman National Society of Soil Science, Bucharest, Romania.

Bierman BJ, Linderman RG, 1981. Quantifying vesicular-arbuscular mycorrhizae: a proposed method towards standardization. New Phytol. 87:63-7.

Brundrett MC, Kendrick B, 1990. The roots and mycorrhizas of herbaceous woodland II. Structural aspects of morphology. New Phytologist 114:469-79.

Chien HF, Kao $\mathrm{CH}, 2000$. Accumulation of ammonium in rice leaves is response to excess cadmium. Plant Sci. 156:111-5.

Clemens S, 2001. Molecular mechanisms of plant metal tolerance and homeostasis. Planta 212:475-86.

Díaz G, Honrubia M, 1993. Infectivity of mine spoils from south east Spain. 2. Mycorrhizal population levels in spoilt sites. Mycorrhiza 4:85-8.

Dick RP, 1997. Soil enzyme activities as integrative indicators of soil health. In: C.E. Pankhurst, B.M. Doube and V.V.S.R. Gupta (eds.) Biological Indicators of Soil Health. CAB International, Wallingford, UK, pp 121-156.

Föhse D, Classen N, Jungk A, 1991. Phosphorus efficiency of plants. II. Significance of root radius, root hairs and cation-anion balance for phosphorus influx in seven plant species. Plant Soil. 132:261-72.

Ford J, Hasselbach L, 2001. Heavy metals in mosses and soils on six transects along the Red Dog Mine haul road Alaska. Western Arctic National Parklands, National Park Service. NPS/AR/NRTR-2001/38. pp 73.

Gerke J, Römer W, Jungk A, 1994. Excretion of citric and malic acid by proteoid roots of Lupinus albus: Effect on soil solution concentra- 
tion of phosphate, iron and aluminium in the proteoid rhizosphere Oxisol and a Luvisol. Z. Pflanzenernähr. Bodenk. 157:289-91.

Hooda V, 2007. Phytoremediation of toxic metals from soil and wastewater. J. Environ. Biol. 28:367-76.

Jackobsen I, 1986. Phosphorus inflow into roots of mycorrhizal and non mycorrhizal peas under field conditions. In: V. Gianinazzi-Pearson and S. Gianinazzi (eds.) Physiological and genetic aspects of Mycorrhiza. INRA, Paris, France, pp 317-322.

Jackson ML, 1973. Soil chemical analysis. Prentice Hall of India Pvt. Ltd., New Delhi, India.

Joner EJ, Leyval C, 1997. Uptake of 109Cd by roots and hypae of a Glomus mosseae/Trifolium subterraneum mycorhiza from soil amended with high and low concentration of cadmium. New Phytol. 135:353-60.

Kimbrough DE, Cohen Y, Winer AM, Creelman L, Mabuni C, 1999. A critical assessment of chromium in the environment. Crit. Rev. Environ. Sci. Technol. 29:1-46.

Koske RE, Gemma JN, Flynn T, 1992. Mycorrhizae in Hawaiian angiosperms: a survey with implications for the origin of native flora. Am. J. Botany 79:853-62.

Lepp NW, 1992. Uptake and accumulation of metals in bacteria and fungi. In: D.C. Adriano (ed.), Biogeochemistry of trace metals. Lewis Publishers, Boca Raton, FL, USA, pp 277-298.

Macnair MR, 2003. The hyperaccumulation of metals by plants. Adv. Bot. Res. 40:64-105.

Marschner H, 1995. Mineral nutrition of higher plants. Academic Press Limited, London, UK.

Muchuweti M, Birkett JW, Chinyanga E, Zvauya R, Scrimshaw MD, Lester JN, 2006. Heavy metal content of vegetables irrigated with mixture of wastewater and sewage sludge in Zimbabwe: implications for human health. Agricult. Ecosyst. Environ. 112:41-8.

Olsen SR, Cole CV, Watanabe FS, Dean LA, 1954. Estimation of available phosphorus in soils by extraction with sodium bicarbonate, USDA, Circular 939. United State Department of Agriculture, USA.

Pal S, Singh HB, Rakshit A. 2012. Impact of Long term wastewater irrigation on the abundanceof arbuscular mycorrhizalspores in the periurban soil of Varanasi. Mycorrhiza News 24:16-9.

Pascual JA,Garcia C, Hernandez T, Moreno JL, Ros M, 2000. Soil microbial activity as a biomarker of degradation and remediation processes. Soil Biol. Biochem. 32:1877-83.

Pawlowska TE, Blaszkowski J, Ruhling A, 1996. The mycorrhizal status of plants colonizing a calamine spoil mound in southern Poland. Mycorrhiza 6:499-505.

Phillips J, Hayman DS, 1970. Improved procedure for clearing roots and staining parasitic and vesicular mycorrizal fungi for rapid assessment of infection. Trans. Br. Mycol. Soc. 55:185-61.

Pulford ID, Watson C, McGregor SD, 2001. Uptake of chromium by trees: prospects for phytoremediation. Environ. Geochem. Health 23:307-11.
Roesti D, Ineichen K, Braissant 0, Redecker D, Wiemken A, Aragno M, 2005. Bacteria associated with spores of the arbuscular mycorrhizal fungi Glomus geosporum and Glomus constrictum. Appl. Environ. Microbiol. 71:6673-9.

Sangi MR, Shahmoradi A, Zolgharnein J, Azimi GH, Ghorbandoost M, 2007. Removal and recovery of heavy metals from aqueous solution using Ulmus carpinifolia and Fraxinus excelsior tree leaves. J. Hazard Mat. 155:513-22.

Sharma RK, Agrawal M, Marshall F, 2007. Heavy metal contamination of soil and vegetables in suburban areas of Varanasi, India. Ecotoxicol. Environ. Safety 66:258-66.

Singh A, Kumar R, Sharma R, Agarwal M, Marshall F, 2010. Risk assessment of heavy metal toxicity through contaminated vegetables from waste water irrigated area of Varanasi, India. Trop. Eco. 51:375-87.

Stefanic C, Ellade G, Chirnageanu J, 1984. Research concerning a biological index of soil fertility. In: 5th Symp. on Soil Biology. Roman National Society of Soil Science, Bucharest, Romania.

Subbiah BV, Asija GL, 1956. A rapid procedure for the determination of available nitrogen in soils. Curr. Sci. 25:259-60.

Sudová R, Jurkiewicz A, Turnau K, Vosátka M, 2007. Persistence of heavy metal tolerance of the arbuscular mycorrhizal fungus Glomus intraradices under different cultivation regimes. Symbiosis 43:71-81.

Tester M, Smith SE, Smith FA, 1987. The phenomenon of non mycorrhizalplants. Can. J. Bot. 65:419-31.

Toljander JF, 2006. Attachment of different soil bacteria to arbuscular mycorrhizal fungal extraradical hyphae is determined by hyphal vitality and fungal species. FEMS Micro. Lett. 254:34-40.

Torresday JL, Videa JRP, Rosa GD, Parsons J, 2005. Phytoremediatoin of heavy metals and study of the metal coordination by X-ray absorption spectroscopy. Coord. Chem. Rev. 249:1797-810.

Walkley AJ, Black CA, 1934. An estimation of the Degtjareff method for determining soil organic matter and a proposed modification of the chromic acid titration method. Soil Sci. 37:29-38.

Wang CL, Tschen JSM, Wang CL, 1997. Factors on the spore germination of arbuscular mycorrhizal fungi, Glomus spp. Fungal Sci. $12: 3-4$.

Weissenhorn I, Leyval C, Berthelin J, 1993. Cd-tolerant arbuscular mycorrhizal (AM) fungi from heavy metal-polluted soils. Plant. Soil 157:247-56

Yost RS, Fox RL, 1979. Contribution of mycorrhizae to P nutrition of crops growing on an oxisol. Agron. J. 71:903-8.

Zhang L, Chen C, 2002. On the general characteristics of plant diversity of Gurbantunggut sandy desert. Acta Ecol. Sinica 22:1923-32.

Zhu YG, Cavagnaro TR, Smith SE, Dickson S, 2001. Backseat driving? Accessing phosphate beyond the rhizosphere-depletion zone. Trends Plant Sci. 6:194-5. 